\title{
PENINGKATAN KEPATUHAN BADAN PUBLIK DALAM PELAKSANAAN UNDANG-UNDANG KETERBUKAAN INFORMASI PUBLIK DI KABUPATEN ACEH BARAT ${ }^{1}$
}

\author{
Afrizal Tjoetra ${ }^{1}$ dan Sudarman ${ }^{2}$ \\ 1Jurusan Ilmu Sosiologi, Fakultas Ilmu Sosial dan Ilmu Politik, Universitas Teuku Umar \\ email: atjoetra@gmail.com \\ 2Jurusan Ilmu Administrasi Negara, Fakultas Ilmu Sosial dan Ilmu Politik, Universitas Teuku \\ Umar \\ Email: darman76alwy@gmail.com
}

\begin{abstract}
Government of Aceh and its regencies show commitment to public information transparency. Nevertheless, the implementation of UU KIP is still not maximized as applicable regulations. This is shown by a number of public information dispute submitted to the Commission on Information Aceh (Komisi Informasi Aceh--KIA) related information which is the obligation of Public Institutions..This research was conducted through a quantitative approach, with the survey method. The aims of research are to determine the readiness of the Public Institutions of West Aceh in implementing the constituent on Public Information, to investigate the Public Information Service in West Aceh Government in providing and announcing regular information and information immediately via the website / bulletin board at the Public Institutions, to know and see the direct efforts of the Public Institutions of West Aceh in preparing and providing the information available at any time to the applicant information, and to submit the feedback to the Public Institutions of West Aceh based on the results of research, so the strengthening of the main PPID and maid PPID in West Aceh. This research was conducted in three stages, namely through independent review, examination of the website and visits to the elected Public Institutions.
\end{abstract}

Keywords: Public Information Transparency, Public Institutions, Public Information.

\section{PENDAHULUAN}

Upaya Pemerintah Indonesia untuk menjalankan good governance and clean goverment semakin nyata. Hal ini dikuatkan dengan disahkannya Undangundang Keterbukaan Informasi Publik (UU KIP) pada 30 April 2008 lalu. Mengingat, keterbukaan informasi publik menjadi keharusan agar pelaksanaan pemerintahan yang baik dan bersih dapat berlangsung. Selain itu, partisipasi publik dalam seluruh proses pemerintahan diharapkan semakin meningkat pasca reformasi untuk memastikan perubahan tetap berlangsung di Nusantara.

${ }^{1}$ Hasil penelitian ini sudah disampaikan dalam The 1st International Conference On Social \& Political Development (ICOSOP), Grand Aston Hotel Medan, November 21-22, 2016 dengan judul INCREASING COMPLIANCE OF PUBLIC INSTITUTIONS WITHIN IMPLEMENTATION THE CONSTITUENT OF PUBLIC INFORMATION TRANSPARENCY IN WEST ACEH. 
UU KIP Nomor 14 Tahun 2008 terdiri dari 16 Bab dan 64 pasal. Berdasarkan Penjelasan Umum UU KIP [2008] dinyatakan bahwa keberadaan UU KIP sangat penting sebagai landasan hukum yang berkaitan dengan (1) hak setiap Orang untuk memperoleh informasi; (2) kewajiban Badan Publik menyediakan dan melayani permintaan informasi secara cepat, tepat waktu, biaya ringan/proporsional, dan cara sederhana; (3) pengecualian bersifat ketat dan terbatas; (4) kewajiban Badan Publik untuk membenahi sistem dokumentasi dan pelayanan Informasi.

Selanjutnya, berdasarkan Penjelasan Umum UU KIP [2008] juga dinyatakan bahwa setiap Badan Publik mempunyai kewajiban untuk membuka akses atas Informasi Publik yang berkaitan dengan Badan Publik untuk masyarakat secara luas. Lingkup Badan Publik dalam UU KIP meliputi lembaga eksekutif, yudikatif, legislatif, serta penyelenggara negara lainnya yang mendapatkan dana dari Anggaran Pendapatan dan Belanja Negara (APBN)/Anggaran Pendapatan dan Belanja Daerah (APBD) dan mencakup pula organisasi non pemerintah, baik yang berbadan hukum maupun yang tidak berbadan hukum, seperti lembaga swadaya masyarakat, perkumpulan, serta organisasi lainnya yang mengelola atau menggunakan dana yang sebahagian atau seluruhnya bersumber dari APBN/APBD, sumbangan masyarakat, dan/atau luar negeri. Mekanisme dan pelaksanaan prinsip keterbukaan diharapkan tercipta tata kelola pemerintahan yang baik serta transparan dan akuntabilitas dengan peran serta masyarakat yang tinggi sebagai salah satu prasyarat untuk mewujudkan demokrasi yang hakiki.

Pemerintahan di Aceh dan Pemerintahan Kabupaten/Kota menunjukkan komitmen yang baik untuk melaksanakan keterbukaan informasi publik. Hal ini diwujudkan dengan membentuk Pejabat Pengelola Informasi dan Dokumentasi (PPID) Utama dan Pembantu pada Satuan Kerja Perangkat Aceh (SKPA). Penunjukan ini dilakukan melalui Surat Keputusan Gubernur Aceh Nomor 480/335/2012. Selanjutnya, Pemerintah Aceh juga membentuk Peraturan tentang Pedoman Pengelolaan Informasi dan Dokumentasi untuk PPID melalui Peraturan Gubernur Aceh Nomor 39 Tahun 2012. Berikutnya, Pemerintah Aceh membentuk Komisi Informasi Aceh (KIA) pada 19 Juni 2012, dengan SK Gubernur Aceh Nomor 555/389/2012 sebagai pelaksanaan UU $\mathrm{KIP}^{2}$.

Selain itu, adanya Surat Edaran Menteri Dalam Negeri Nomor 188.2/7266/SJ/2013 tentang Percepatan Pembentukan dan Operasional PPID Tingkat Provinsi dan Kabupaten/Kota ${ }^{3}$, sudah direspon oleh sejumlah

2 Peraturan Gubernur Nomor 39 Tahun 2012 Tentang Pedoman Pengelolaan Informasi dan Dokumentasi Di Lingkungan Pemerintahan Aceh.

3 Permendagri No 35 Tahun 2010 Tentang Pedoman Pengelolaan dan PelayananInformasi Dokumentasi di Lingkungan Depdagri dan Pemerintah Daerah. 
Bupati/Walikota di Aceh dengan menerbitkan Surat Keputusan Pengangkatan/penunjukan PPID di tingkat Kabupaten/Kota. Sampai saat ini sudah terbentuk 23 PPID Kabupaten/Kota, termasuk di Kabupaten Aceh Barat.

Meskipun demikian, pelaksanaan UU KIP masih belum maksimal sesuai dengan ketentuan yang berlaku. Hal ini ditunjukkan dengan sejumlah sengketa informasi publik di KIA terkait informasi yang menjadi kewajiban badan publik. Merujuk hasil evaluasi KIA selama tiga tahun (2013-2015) lalu, diketahui bahwa secara umum pelaksanaan UU KIP di Aceh belum menggembirakan dan masih diperlukan upaya serius untuk melaksanakan ketentuan yang sudah ditetapkan. Berikutnya, juga diketahui masih rendahnya kepatuhan, komitmen dan dukungan penentu kebijakan pada Dinas/Badan/Instansi sebagai Badan Publik Pemerintah untuk melaksanakan UU KIP. Hal ini ditunjukkan dengan kurangnya ketersediaan layanan, terbatasnya anggaran untuk melaksanakan fungsi dan kegiatan PPID, bahkan terdapat PPID yang belum mendapat dukungan anggaran dari APBA/APBK. Selain itu, masih terbatasnya sosialisasi UU KIP dan Perki - SLIP (Peraturan Komisi Informasi - Standar Layanan Informasi Publik), sehingga masih banyak pejabat publik serta pelaksana di badan publik dan masyarakat belum terpapar dengan keberadaan UU KIP4.

Upaya Pemerintahan di Aceh menjadi bagian yang tak terpisahkan dari penjelasan umum UU KIP yang menyatakan bahwa Undang-Undang Dasar Negara Republik Indonesia Tahun 1945 Pasal 28 F menyebutkan "bahwa setiap Orang berhak untuk berkomunikasi dan memperoleh Informasi untuk mengembangkan pribadi dan lingkungan sosialnya, serta berhak untuk mencari, memperoleh, memiliki, dan menyimpan Informasi dengan menggunakan segala jenis saluran yang tersedia". Untuk memberikan jaminan terhadap semua orang dalam memperoleh informasi, perlu dibentuk undangundang yang mengatur tentang keterbukaan Informasi Publik. Fungsi maksimal ini diperlukan, mengingat hak untuk memperoleh Informasi merupakan hak asasi manusia sebagai salah satu wujud dari kehidupan berbangsa dan bernegara yang demokratis.

Selanjutnya, dinyatakan bahwa salah satu elemen penting dalam mewujudkan penyelenggaraan negara yang terbuka adalah hak publik untuk memperoleh informasi sesuai dengan peraturan perundang-undangan. Hak atas Informasi menjadi sangat penting karena makin terbuka penyelenggaraan

${ }^{4}$ Komisi Informasi Aceh, 2013. Laporan Evaluasi Satuan Kerja Perangkat Aceh (SKPA) dan Pemerintah Kabupaten/kota Se Aceh Dalam Pelaksanaan Keterbukaan dan Layanan Informasi Publik, Komisi Informasi Aceh (KIA), Banda Aceh dan Laporan Evaluasi Implementasi Keterbukaan Informasi Publik pada Satuan Kerja Perangkat Aceh, Pemerintah Kabupaten/ kota, Perguruan Tinggi Negeri dan Partai Politik di Aceh - Tahun 2015, Komisi Informasi Aceh (KIA), Banda Aceh dan Komisi Informasi Aceh, 2014 dan 2015. Laporan Evaluasi Keterbukaan Informasi Publik di Aceh, Komisi Informasi Aceh (KIA), Banda Aceh. 
negara untuk diawasi publik, penyelenggaraan negara tersebut makin dapat dipertanggungjawabkan. Hak setiap Orang untuk memperoleh informasi juga relevan untuk meningkatkan kualitas pelibatan masyarakat dalam proses pengambilan keputusan publik. Partisipasi atau pelibatan masyarakat tidak banyak berarti tanpa jaminan keterbukaan Informasi Publik (Penjelasan umum UU KIP, 2008).

Dengan membuka akses publik terhadap informasi diharapkan Badan Publik termotivasi untuk bertanggungjawab dan berorientasi pada pelayanan rakyat yang sebaik-baiknya. Dengan demikian, hal itu dapat mempercepat perwujudan pemerintahan yang terbuka yang merupakan upaya strategis mencegah praktik korupsi, kolusi, dan nepotisme $(\mathrm{KKN})$, dan terciptanya kepemerintahan yang baik (good governance).

Sejumlah peraturan perundang-undangan, baik dari pusat maupun Pemerintah Aceh ditujukan untuk meningkatkan kepatuhan badan publik dalam melaksanakan UU KIP. Namun, hasil observasi awal di tingkat PPID Utama dan PPID Pembantu (Satuan Kerja Perangkat Kabupaten-SKPK) di Kabupaten Aceh Barat ditemukan sejumlah kelemahan, antara lain :

1. Belum adanya Peraturan Bupati tentang Standar Operasional Prosedur (SOP) di PPID Pembantu untuk melaksanakan UU KIP.

2. Belum adanya Daftar Informasi Publik (DIP) yang dapat diakses publik dan informasi yang dikecualikan (dirahasiakan).

3. Belum tersedianya layanan informasi publik melalui website sesuai dengan ketentuan UU KIP dan Perki SLIP, terutama informasi yang wajib tersedia secara berkala, informasi yang wajib setiap saat, serta informasi yang dikecualikan.

4. PPID Utama dan PPID Pembantu sebagian besar belum memiliki sarana dan prasarana penunjang dalam melaksanakan UU KIP, seperti perangkat komputer yang memadai, meja layanan, serta sarana penunjang administrasi lainnya.

Berdasarkan beberapa hal tersebut di atas, peneliti hendak memastikan pelaksanaan dan peningkatan kepatuhan badan publik dalam melaksanakan UU KIP di Kabupaten Aceh Barat. Proses ini sebagai bentuk dukungan agar pelaksanaan UU KIP di Aceh Barat dapat berlangsung efektif. Sehingga bermuara pada pelaksanaan pemerintahan yang baik dan bersih serta meningkatkan partisipasi publik dalam pembangunan.

Untuk itu, peneliti menyampaikan rumusan masalah sebagai berikut:

1. Bagaimana kepatuhan Pemerintahan di Kabupaten Aceh Barat melalui PPID Pembantu dalam melaksanakan UU KIP? 
2. Apasaja yang dapat memengaruhi kepatuhan aparatur Pemerintahan di Kabupaten Aceh Barat dalam melaksanakan UU KIP?

\subsection{Tujuan Penelitian}

Penelitian ini memiliki dua tujuan, yaitu:

1. Tujuan Umum

Untuk meningkatkan kepatuhan Badan Publik Pemerintah di Kabupaten Aceh dalam melaksanakan UU KIP.

2. Tujuan Khusus

Tujuan khusus pelaksanaan penelitian tentang Keterbukaan Informasi Publik sebagai berikut:

2.1. Mengetahui kesiapan PPID Pembantu Pemerintah Kabupaten Aceh Barat dalam melaksanakan UU KIP melalui kajian mandiri (self assessment).

2.2. Mengetahui Layanan Informasi Publik pada PPID Pembantu Pemerintah Kabupaten Aceh Barat dalam menyediakan dan mengumumkan informasi berkala dan informasi serta merta (sesuai kewajiban pasal 9 dan pasal 10 UU KIP juncto pasal 11 dan pasal 12 Perki-SLIP), melalui website/papan pengumuman di Badan Publik.

2.3. Mengetahui dan melihat langsung upaya PPID Pembantu Pemerintah Kabupaten Aceh Barat dalam menyiapkan dan menyediakan informasi yang tersedia setiap saat kepada pemohon informasi (kewajiban pasal 11 UU KIP, juncto pasal 13 Perki-SLIP).

2.4. Menyampaikan umpan balik kepada PPID Pembantu Pemerintah Kabupaten Aceh Barat berdasarkan hasil penelitian, sehingga adanya penguatan terhadap PPID Pembantu di SKPK Kabupaten Aceh Barat.

Penelitian tentang evaluasi kepatuhan Badan Publik dalam melaksanakan UU KIP di Aceh telah dilakukan oleh Komisi Informasi Aceh sejak 2013 hingga 2015. Ruang lingkup kajian pada jenjang provinsi dan Pejabat Pengelola Informasi dan Dokumentasi (PPID) Utama Kabupaten/Kota, Partai Politik, dan Perguruan Tinggi Negeri. Berdasarkan evaluasi yang dilakukan KIA terhadap Badan Publik 2015 lalu, PPID Utama Aceh Barat menduduki peringkat kedua dari 23 kabupaten/kota di Aceh dengan nilai 55,92 . Penilaian hasil gabungan antara SAQ, website, dan kunjungan lapangan ${ }^{5}$.

Selama penelitian pada PPID Pembantu di Aceh Barat, peneliti menggunakan pendekatan dan kuesioner yang dilaksanakan oleh KIA dalam melakukan evaluasi Badan Publik di Aceh. Hanya saja cakupan Badan Publik

5Komisi Informasi Aceh, 2014 dan 2015. Laporan Evaluasi Keterbukaan Informasi Publik di Aceh, Komisi Informasi Aceh (KIA), Banda Aceh. 
Community: Volume 3, Nomor 1, April 2017

ISSN: 2477-5746

berbeda serta fokus pada PPID Pembantu SKPK di Kabupaten Aceh Barat. Penetapan PPID Pembantu ini merujuk Keputusan Bupati Aceh Barat Nomor 619 Tahun 2014 tentang Penunjukkan Pejabat Pengelola Informasi dan Dokumentasi Di Lingkungan Pemerintah Kabupaten Aceh Barat. PPID Pembantu (SKPK) dimaksud sebanyak 35 Dinas/Badan/Kantor6.

\section{TINJAUANPUSTAKA}

Penelitian ini merujuk pada hasil evaluasi Badan Publik yang dilakukan oleh KIA sejak 2013 hingga 2015. Hanya saja, cakupan evaluasi yang dilakukan mencakup Badan Publik level provinsi dan Pejabat Pengelola Informasi dan Dokumentasi (PPID) Utama kabupaten/kota di Aceh. Sedangkan penelitian yang dilakukan oleh peneliti mencakup Badan Publik Pemerintah di Kabupaten Aceh Barat.

Rujukan penelitian ini sebagaimana Katherine dan Susan (1998) yang menyatakan bahwa partisipasi publik merupakan elemen mendasar dalam kerangka perwujudan good governance. Bahkan, dalam perkembangannya menunjukkan adanya suatu keharusan bagi pemerintah (dalam arti luas) untuk lebih akuntabel kepada masyarakat yang diwakilinya tentang bagaimana input dari masyarakat digunakan dalam perumusan kebijakan.

Selanjutnya, dinyatakan bahwa efektifitas partisipasi publik memerlukan dukungan sumber daya tertentu yang harus dimiliki oleh publik maupun pemerintah7 ${ }^{7}$ Sumber daya tersebut adalah:

1) Perubahan perilaku dan institusi pemerintahan. Institusi pemerintahan tradisional dengan jenjang hirarkis organisasi yang panjang, perumusan kebijakan yang mendasarkan pada jenjang hirarkis kewenangan, ketertutupan, monopoli informasi, merupakan hambatan besar bagi pelaksanaan partisipasi publik yang mensyaratkan keterbukaan, fleksibilitas, responsivitas maupun akuntabel.

2) Peningkatan kapasitas asosiasi atau organisasi publik. Peningkatan ini juga harus didukung oleh pemerintah, terutama melalui program ataupun alokasi dana.

3) Kemudahan publik untuk mendapatkan informasi. Hal ini dilatarbelakangi oleh kenyataan bahwa seringkali isu atau masalah yang diangkat oleh publik tidak disertai dengan data yang akurat, terutama yang menyangkut kebijakan atau program pemerintah, sehingga faktor emosi lebih mendominasi.

6Keputusan Bupati Aceh Barat Nomor 619 Tahun 2014 tentang Penunjukkan Pejabat Pengelola Informasi dan Dokumentasi Di Lingkungan Pemerintah Kabupaten Aceh Barat.

7 Katherine A. Graham and Susan D. Philips, 1998. "Making Public Participation More Effective: Issue for Local Government", dalam KA Graham and SD Philips (ed) Citizen Engagment: Lesson In Participation From Local Government, The Institute of Public Administration on Canada, Toronto, Ontario, Canada. 


\section{METODEPENELITIAN}

Penelitian ini dilakukan melalui pendekatan kuantitatif dengan metode survey. Survey dalam penelitian ini dilakukan terhadap 35 PPID Pembantu SKPK Pemerintah Kabupaten di Aceh Barat. Metode survey yang digunakan dilaksanakan secara lengkap atau sensus. Secara normatif, survey digunakan untuk memaparkan data dari objek penelitian, menginterpretasikan dan menganalisisnya secara sistematis.

\subsection{Lokasi dan Waktu Pelaksanaan Penelitian}

Lokasi penelitian dilaksanakan di Kabupaten Aceh Barat, dengan sampel penelitian 35 PPID Pembantu SKPK di lingkungan Pemerintah Aceh Barat. Waktu pelaksanaan penelitian dimulai pada bulan Mei sampai dengan November 2016.

\subsection{Jenis dan Sumber Data}

Penelitian ini merupakan suatu studi kasus dengan jenis data primer dan sekunder. Dalam penelitian ini data primer adalah jawaban langsung dari informan yang berkaitan dengan persepsi PPID terhadap UU KIP. Data primer bertujuan untuk memenuhi kebutuhan dalam penelitian. Data primer ini seperti dikatakan Bagong Suyanto dan Sutinah (2008:55) bahwa "data primer yaitu data yang diperoleh langsung dari obyek yang akan diteliti (responden).

Pengumpulan data primer dengan menggunakan instrumen penelitian, yaitu interview guide dan wawancara tidak berstruktur. Sedangkan menurut Bungin (2008:122) "data sekunder adalah data yang diperoleh dari sumber kedua atau sumber sekunder dari data yang kita butuhkan misalnya melalui dokumen". Data sekunder itu merupakan data yang diperoleh oleh peneliti dari sumber-sumber yang telah ada. Diketahui bahwa sebelum penelitian dilakukan oleh peneliti, data sekunder memang sudah tersedia, data ini diperoleh dari studi kepustakaan, dokumen, laporan, yang berkaitan dengan kajian penelitian.

Dalam penelitian ini yang dijadikan sumber data sekunder adalah datadata dari beberapa literatur seperti laporan dan buku-buku yang berkaitan dengan persepsi PPID terhadap UU KIP.

\subsection{Metode Pengumpulan Data}

Proses penelitian Badan Publik ini dibagi dalam dua tahap, yaitu :

1. Tahap Pertama; disebut dengan self assessment (kajian mandiri) oleh Badan Publik. Pada tahap ini, peneliti mengirimkan kuesioner yang 
harus diisi oleh PPID di Badan Publik, dan selanjutnya dilakukan verifikasi website PPID terkait kewajiban publikasi informasi berkala.

2. Tahap Kedua; disebut dengan kunjungan lapangan. Pada tahap ini, peneliti menetapkan sejumlah Badan Publik terpilih sesuai dengan penetapan pemeringkatan awal dan dipilih Badan Publik (10 \% - 15 \%) yang masuk nominasi.

\subsection{Instrumen Penelitian}

Instrumen penelitian Badan Publik adalah suatu alat ukur yang dikembangkan dalam bentuk tabel yang berisi daftar / check list yang memuat pertanyaan dan kalimat untuk mengetahui dan memastikan PPID Badan Publik melaksanakan atau tidaknya ketentuan standar layanan informasi publik sebagaimana diwajibkan oleh UU KIP dan Peraturan Komisi Informasi tentang Standar Layanan Informasi Publik (PERKI SLIP, 2010).

Instrumen penelitian kepatuhan Badan Publik di Kabupaten Aceh Barat ini terdiri dari:

1. Instrumen Kajian Mandiri (Self Assessment Questionaire/SAQ), yang diperuntukkan pada Badan Publik penyelenggara pemerintahan. Instrumen SAQ ini adalah daftar tilik atau pertanyaan untuk mengukur sejauhmana standar layanan informasi yang sudah dijalankan oleh masing-masing Badan Publik secara mandiri. Instrumen ini mencakup pengukuran 3 (tiga) variabel yaitu mengumumkan, menyediakan dan variabel melayani.

2. Instrumen kajian dan verifikasi website/situs Badan Publik di Kabupaten Aceh Barat, yaitu daftar tilik untuk mengukur layanan informasi Badan Publik dalam menyediakan dan menyampaikan / mengumumkan informasi berkala kepada masyarakat melalui website/situs Badan Publik.

3. Instrumen Visitasi, yaitu daftar tilik yang digunakan pada saat kunjungan lapangan di Badan Publik Pemerintah Kabupaten Aceh Barat untuk mengukur ketersediaan informasi setiap saat dan layanan informasi oleh PPID (variabel menyediakan dan melayani).

Alat ukur yang akan digunakan adalah berbentuk kuisioner yang terdiri dari 3 (tiga) variabel dan indikator yaitu;

a. Mengumumkan

Variabel ini mengacu pada pasal 9 UU KIP, sementara sub indikatornya merujuk pada PERKI-SLIP No. 1 Tahun 2000, pasal 11. Terkait indikator kewajiban menyediakan dan mengumumkan informasi berkala terdiri dari: 

1. Profil Badan Publik
2. Laporan Keuangan
3. Laporan akses informasi
4. PengaduanPenyalahgunaan dan pertanggungjawaban wewenang + pengaduan $\mathrm{BP}$
5. Barang dan jasa
6. Regulasi

b. Menyediakan

Variabel menyediakan mengacu pada kewajiban menyediakan informasi setiap saat, pasal 11 UU KIP, dengan indikator sebagai berikut:

1. Daftar Informasi Publik (DIP)

2. Peringatan dini

3. Keputusan Badan Publik

4. Surat perjanjian dengan pihak ketiga

5. Data statistik

6. Surat menyurat

7. Rencana strategis

8. SOP pelayanan masyarakat

9. Informasi mengenai PPID (SK, struktur PPID)

10. Informasi mengenai penindakan atas pelanggaran yang dilakukan oleh pegawai Badan Publik

11. Daftar penelitian

12. Hasil penelitian

13. Informasi mengenai LHKPN yang telah diverifikasi oleh KPK

c. Melayani

Dalam pelaksanaan evaluasi penyelenggara kepemerintahan dan Badan Publik pemerintah, ke 3 (tiga) indikator yang digunakan sebagai berikut:

1. Sarana layanan informasi (Meja Informasi, Petugas Informasi, Papan pengumuman)

2. Laporan layanan informasi publik ke Komisi Informasi

3. Mengembangkan sistem informasi

Skema umum daftar tilik / kuisioner sebagai berikut ${ }^{8}$ :

${ }^{8}$ Komisi Informasi Aceh, 2014 dan 2015. Laporan Evaluasi Keterbukaan Informasi Publik di Aceh, Komisi Informasi Aceh (KIA), Banda Aceh. 


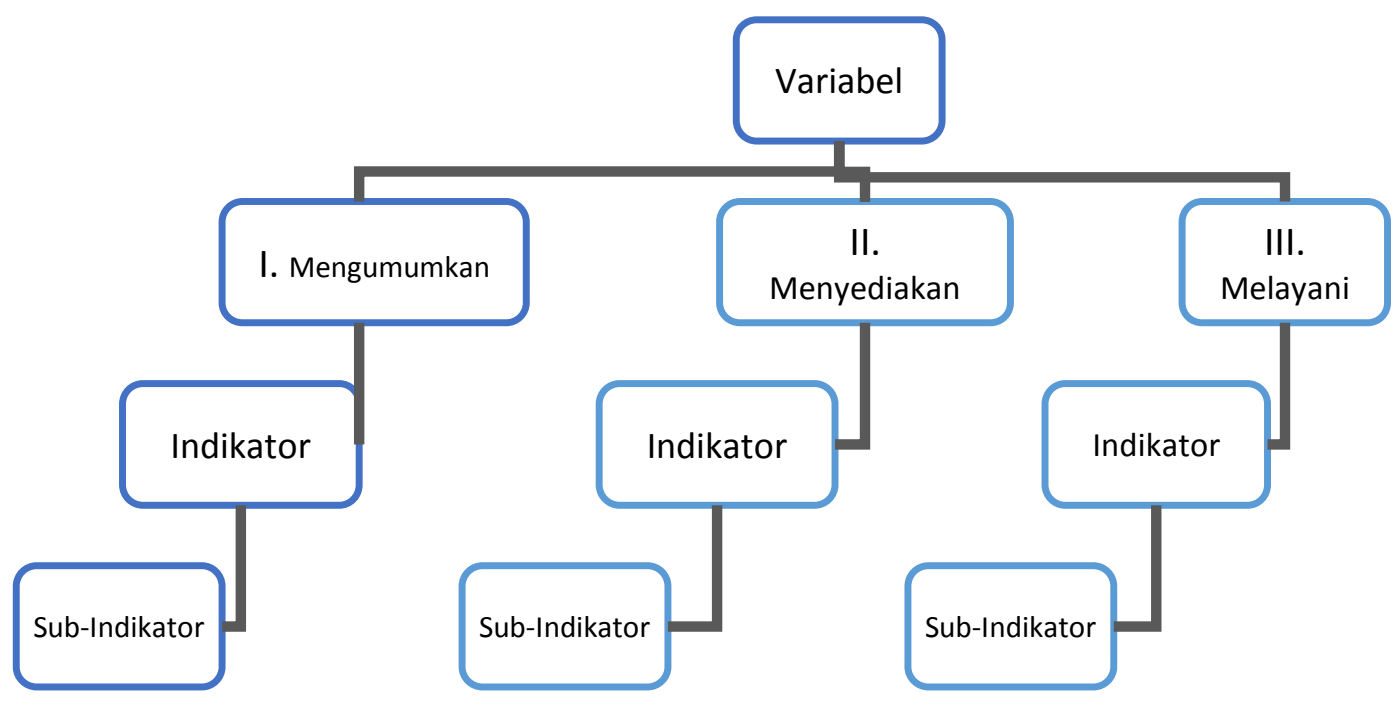

Berikut skema penilaian yang dilakukan dalam evaluasi kepatuhan Badan Publik di Aceh Barat dalam melaksanakan UU KIP melalui tahap 1 dan tahap 29:

\section{*Persentase}

\section{*SAQ}

1. Mengumumkan

2. Menyediakan

3. Melayani

TOTAL
$40 \%$

$30 \%$

$30 \%$

Total SAQ x (25\%)
$(25 \%)$

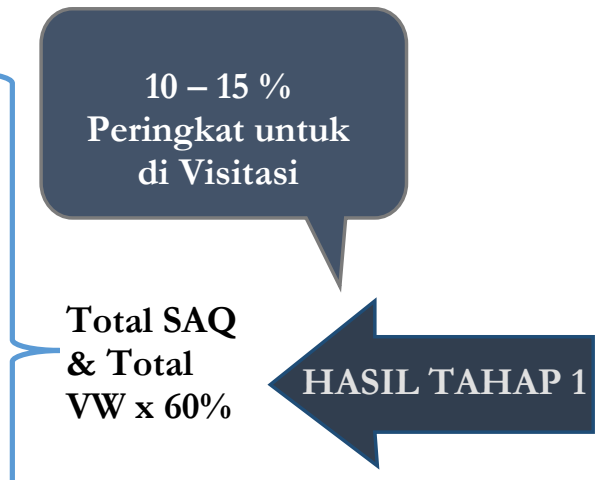

*Verifikasi Website (VW) $\longrightarrow(75 \%)$

TOTAL

$\rightarrow$ Total VW x (75\%)

*Visitasi

$(40 \%)$

TOTAL $\rightarrow$ Total Visitasix (40\%)

${ }^{9}$ Ibid. 


\section{TEMUAN DANPEMBAHASAN}

Berdasarkan tahapan yang sudah ditetapkan di atas, tahap pertama peneliti melakukan pembagian kuesioner pada 35 PPID Pembantu di Kabupaten Aceh Barat. Proses ini disebut Self Assesment Quesioner (SAQ) yang dilakukan sejak 26 - 30 September 2016. Kuesioner tersebut diisi secara mandiri oleh PPID Pembantu. Hasil penilaian tersebut berkaitan dengan informasi yang harus disediakan oleh PPID dengan hasil sebagai berikut :

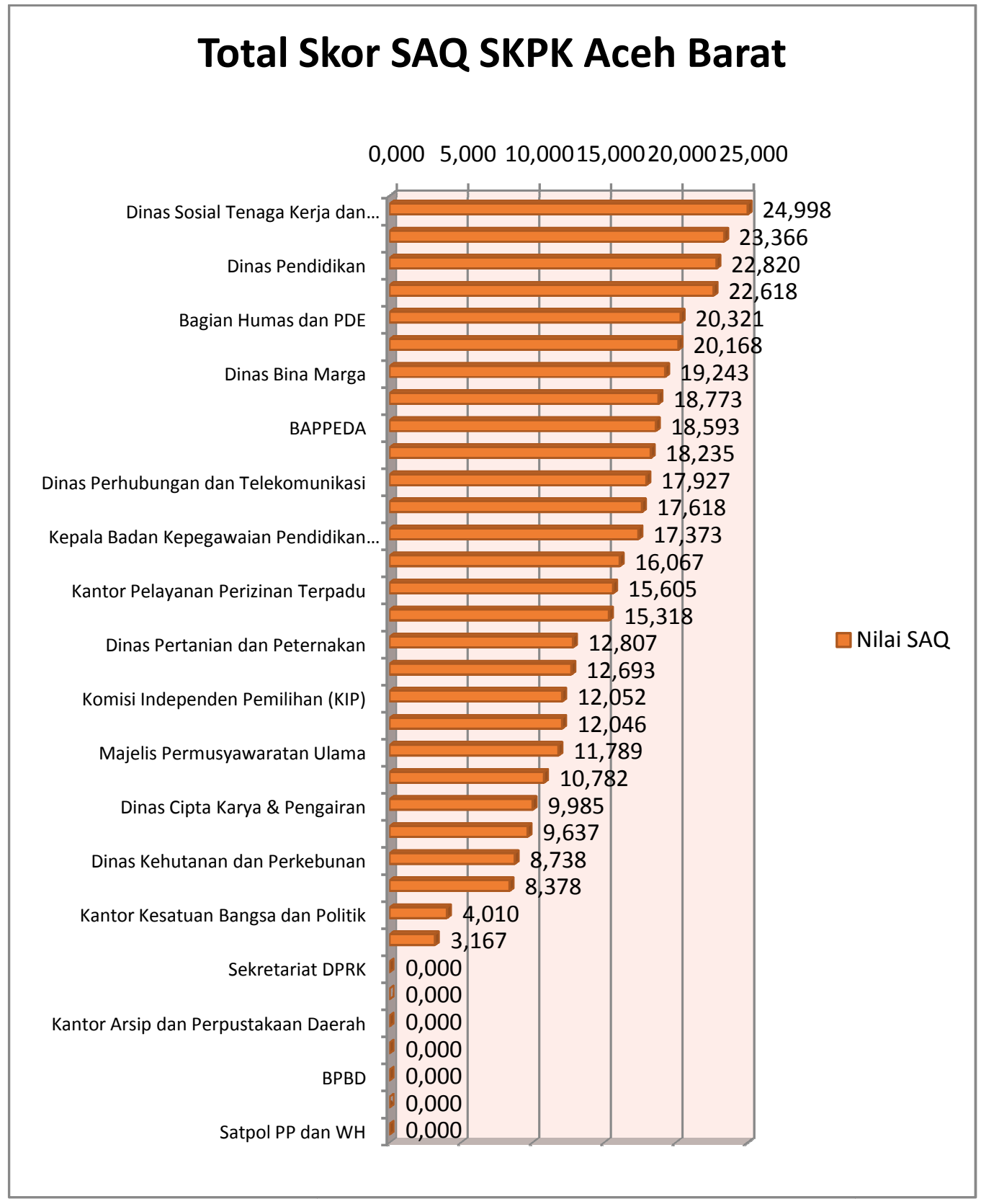

Grafik 1 : Hasil Penilaian SAQ SKPK di Aceh Barat 
Sesuai hasil penilaian dipahami bahwa pelayanan informasi publik pada PPID Pembantu belum maksimal. Hal ini ditunjukkan dengan jumlah nilai yang dihasilkan masih dibawah 25\% dengan 13 variabel yang harus dilakukan selama pelayanan informasi pada publik. Selain itu, kurangnya nilai yang diperoleh menunjukkan bahwa PPID Pembantu di SKPK Aceh Barat belum melaksanakan seluruh ketentuan yang diatur dalam UU KIP serta Perki SLIP. Apalagi masih terdapat 7 PPID Pembantu SKPK yang tidak memperoleh nilai dalam tahapan SAQ ini, dengan rincian 6 PPID Pembantu yang tidak memberi jawaban dan 1 (satu) PPID Pembantu yang tidak mengembalikan kuesioner yakni PPID Pembantu Dinas Syariat Islam.

Berikutnya, peneliti melakukan kajian website tiap SKPK. Kajian ini dilakukan selama 7 hari kerja sejak 12-18 Oktober 2016 dengan hasil sebagai berikut :

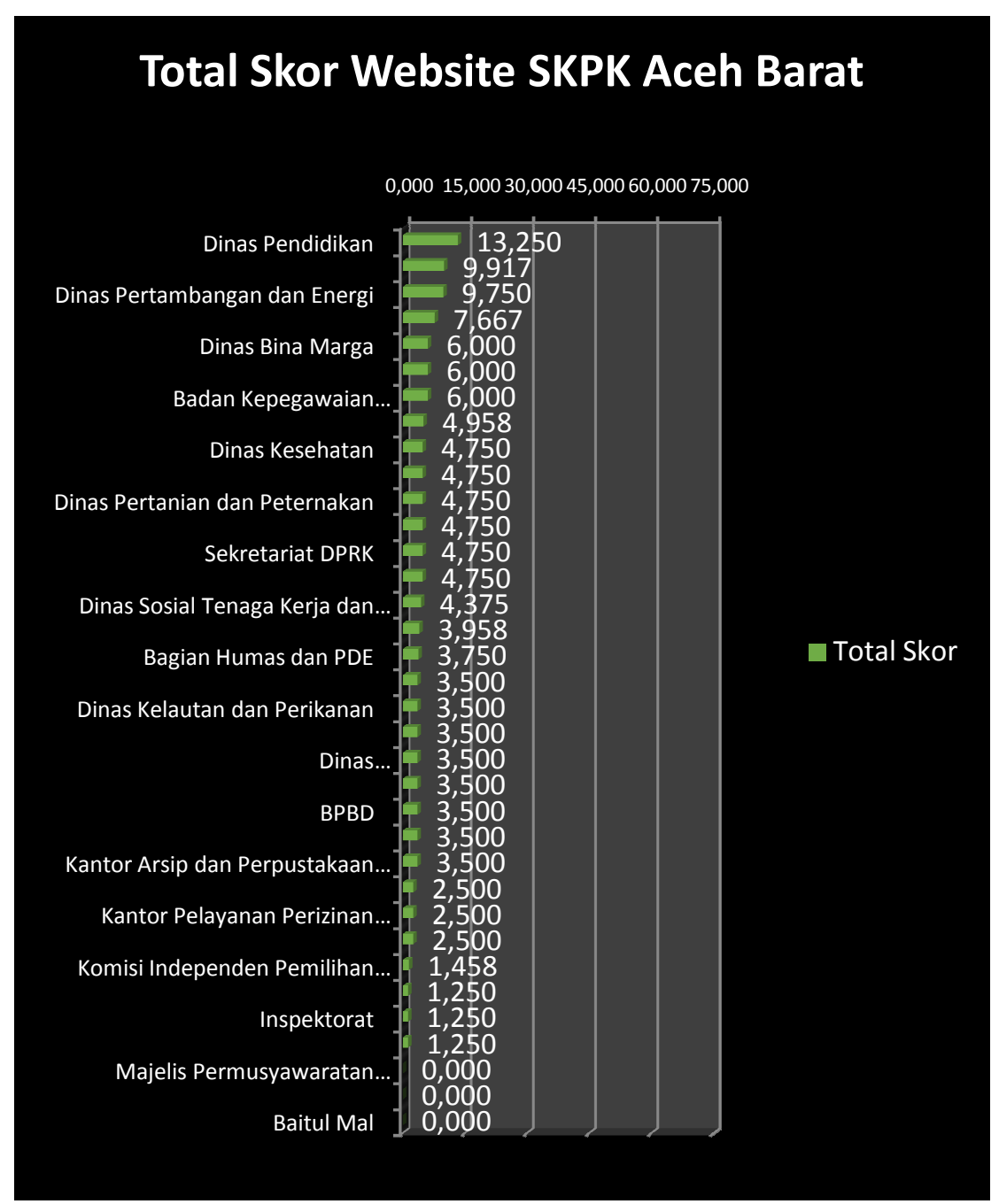

Grafik 2 : Hasil Penilaian Website SKPK di Aceh Barat 
Sesuai hasil penilaian website pada PPID Pembantu difahami bahwa penyediaan informasi publik terkait 7 (tujuh) variabel masih belum maksimal dilakukan oleh PPID Pembantu SKPK. Berdasarkan hasil penilaian website tiap PPID Pembantu SKPK secara umum masih dibawah 15\%. Hal ini mengkonfirmasi bahwa informasi yang wajib diumumkan masih belum optimal sebagaimana yang telah ditetapkan dalam UU KIP dan Perki SLIP. Bahkan, diperoleh informasi bahwa masih adanya PPID Pembantu SKPK yang belum memiliki website sebanyak 3 SKPK.

Berikutnya, peneliti melakukan penggabungan penilaian SAQ dan website untuk memperoleh peringkat 10 PPID Pembantu SKPK di Aceh Barat. Hasil penilaian gabungan antara SAQ dan penilaian website dapat dilihat sebagai berikut :

Tabel : Penilaian Gabungan SAQ dan Website

\begin{tabular}{|c|c|c|c|c|}
\hline Peringkat & Nama Badan Publik & SAQ & Website & $\begin{array}{l}\text { SAQ + } \\
\text { Website }\end{array}$ \\
\hline 1 & Dinas Pendidikan & 22.820 & 13.250 & 36.070 \\
\hline 2 & $\begin{array}{l}\text { Kantor Pemberdayaan Perempuan } \\
\text { dan Keluarga Sejahtera }\end{array}$ & 20.168 & 9.917 & 30.085 \\
\hline 3 & $\begin{array}{l}\text { Dinas Sosial Tenaga Kerja dan } \\
\text { Transmigrasi }\end{array}$ & 24.998 & 4.375 & 29.373 \\
\hline 4 & $\begin{array}{l}\text { Dinas Kependudukan dan Pencatatan } \\
\text { Sipil }\end{array}$ & 23.366 & 3.500 & 26.866 \\
\hline 5 & BAPPEDA & 18.593 & 7.667 & 26.260 \\
\hline 6 & Dinas Bina Marga & 19.243 & 6.000 & 25.243 \\
\hline 7 & $\begin{array}{l}\text { Badan Lingkungan Hidup dan } \\
\text { Kebersihan }\end{array}$ & 22.618 & 2.500 & 25.118 \\
\hline 8 & Bagian Humas dan PDE & 20.321 & 3.750 & 24.071 \\
\hline 9 & $\begin{array}{l}\text { Badan Kepegawaian Pendidikan dan } \\
\text { Pelatihan }\end{array}$ & 17.373 & 6.000 & 23.373 \\
\hline 10 & $\begin{array}{l}\text { Dinas Koperasi, UKM, Perindustrian } \\
\text { dan Perdagangan }\end{array}$ & 18.235 & 3.500 & 21.735 \\
\hline 11 & Dinas Kelautan dan Perikanan & 16.067 & 3.500 & 19.567 \\
\hline 12 & $\begin{array}{l}\text { Dinas Perhubungan dan } \\
\text { Telekomunikasi }\end{array}$ & 17.927 & 1.250 & 19.177 \\
\hline 13 & Inspektorat & 17.618 & 1.250 & 18.868 \\
\hline
\end{tabular}


Community: Volume 3, Nomor 1, April 2017

ISSN: 2477-5746

\begin{tabular}{|c|c|c|c|c|}
\hline 14 & Disbudparpora & 15.318 & 3.500 & 18.818 \\
\hline 15 & Sekretariat Majelis Adat Aceh (MAA) & 18.773 & 0.000 & 18.773 \\
\hline 16 & Kantor Pelayanan Perizinan Terpadu & 15.605 & 2.500 & 18.105 \\
\hline 17 & Sekretariat Majelis Pendidikan Daerah & 12.693 & 4.958 & 17.651 \\
\hline 18 & Dinas Pertanian dan Peternakan & 12.807 & 4.750 & 17.557 \\
\hline 19 & Dinas Kesehatan & 12.046 & 4.750 & 16.796 \\
\hline 20 & DPKKD & 9.637 & 6.000 & 15.637 \\
\hline 21 & Dinas Cipta Karya \& Pengairan & 9.985 & 4.750 & 14.735 \\
\hline 22 & Komisi Independen Pemilihan (KIP) & 12.052 & 1.458 & 13.510 \\
\hline 23 & Dinas Kehutanan dan Perkebunan & 8.738 & 4.750 & 13.488 \\
\hline 24 & Badan Pemberdayaan Masyarakat & 8.378 & 4.750 & 13.128 \\
\hline 25 & Dinas Pertambangan dan Energi & 3.167 & 9.750 & 12.917 \\
\hline 26 & $\begin{array}{l}\text { Sekretariat Majelis Permusyawaratan } \\
\text { Ulama }\end{array}$ & 11.789 & 0.000 & 11.789 \\
\hline 27 & Baitul Mal & 10.782 & 0.000 & 10.782 \\
\hline 28 & Kantor Kesatuan Bangsa dan Politik & 4.010 & 1.250 & 5.260 \\
\hline 29 & Sekretariat DPRK & 0.000 & 4.750 & 4.750 \\
\hline 30 & RSU Cut Nyak Dhien & 0.000 & 3.958 & 3.958 \\
\hline 31 & $\begin{array}{l}\text { Kantor Arsip dan Perpustakaan } \\
\text { Daerah }\end{array}$ & 0.000 & 3.500 & 3.500 \\
\hline 32 & Dinas Syariat Islam & 0.000 & 3.500 & 3.500 \\
\hline 33 & BPBD & 0.000 & 3.500 & 3.500 \\
\hline 34 & BP4K & 0.000 & 3.500 & 3.500 \\
\hline 35 & Satpol PP dan WH & 0.000 & 2.500 & 2.500 \\
\hline
\end{tabular}

Berikutnya, hasil penilaian gabungan juga dapat dilihat sebagai berikut: 


\section{Total Skor SAQ + Website SKPK Aceh Barat}

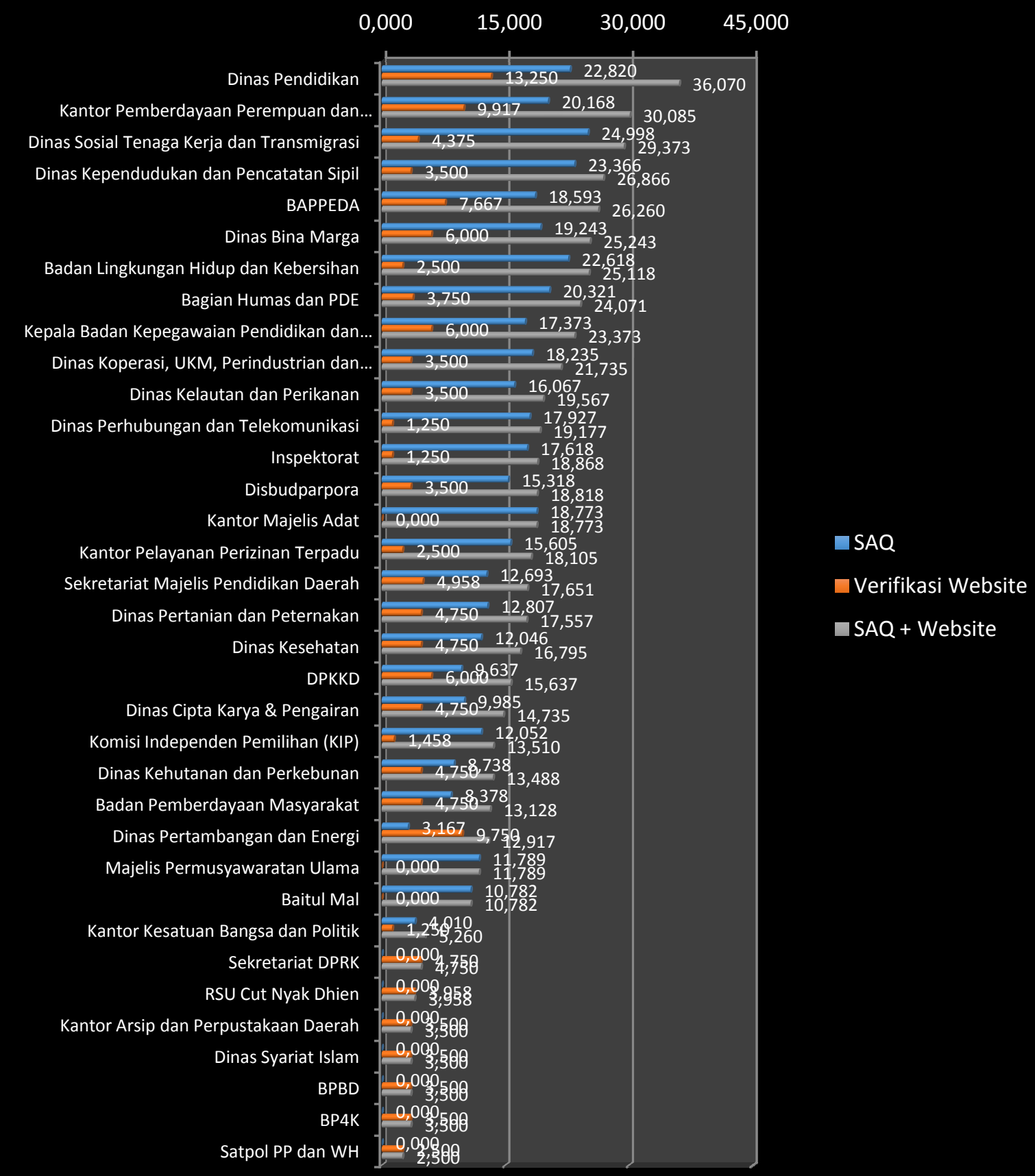

Grafik 3 : Hasil Penilaian Gabungan SAQ dan Website untuk SKPK di Aceh Barat. 
Community: Volume 3, Nomor 1, April 2017

ISSN: 2477-5746

Selanjutnya penilaian kunjungan lapangan dapat dilihat sebagai berikut:

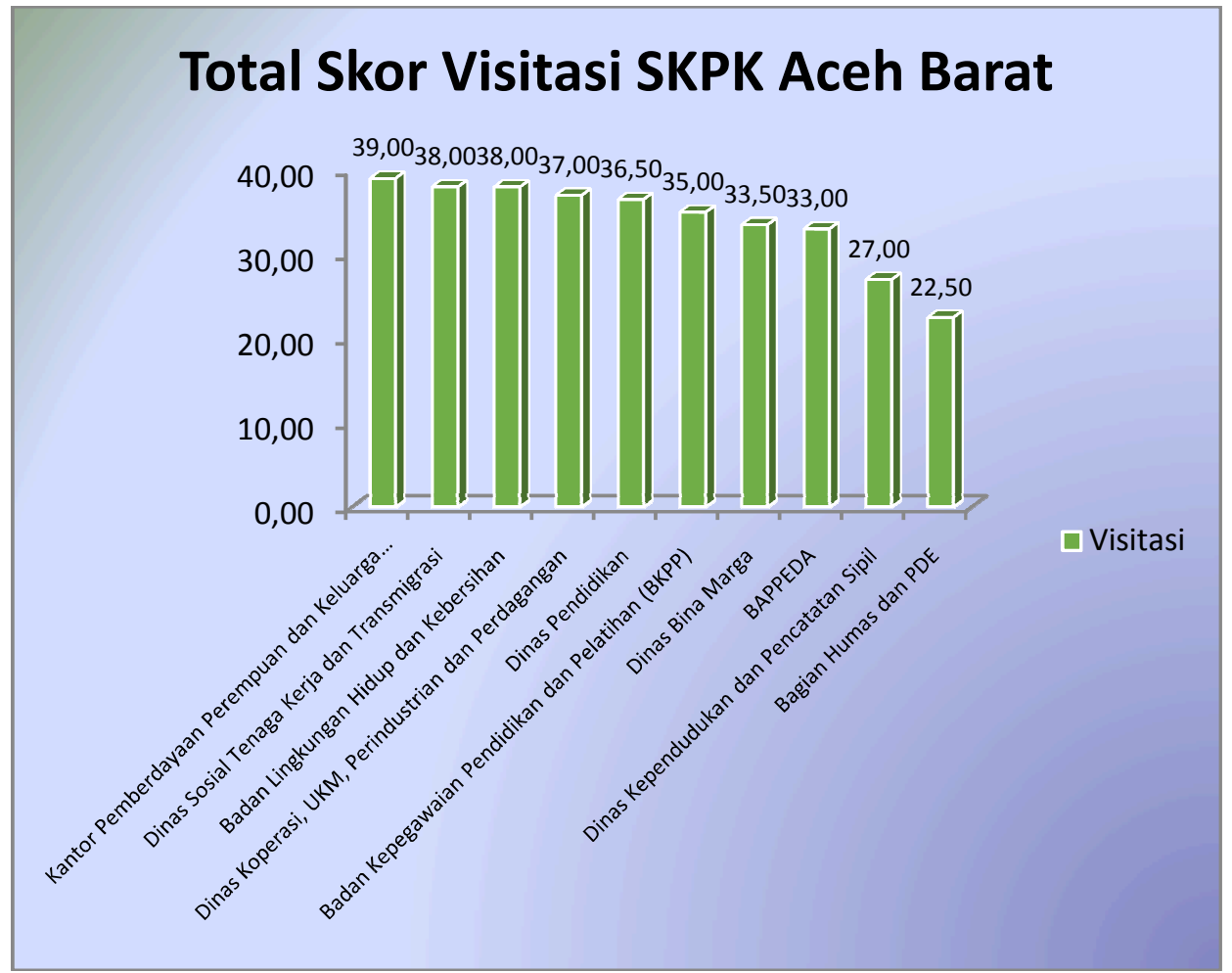

Grafik 4 : Total Skor Visitasi PPID Pembantu SKPK

Sedangkan penilaian gabungan antara SAQ, kajian website, dan visitasi lapangan sebagai berikut :

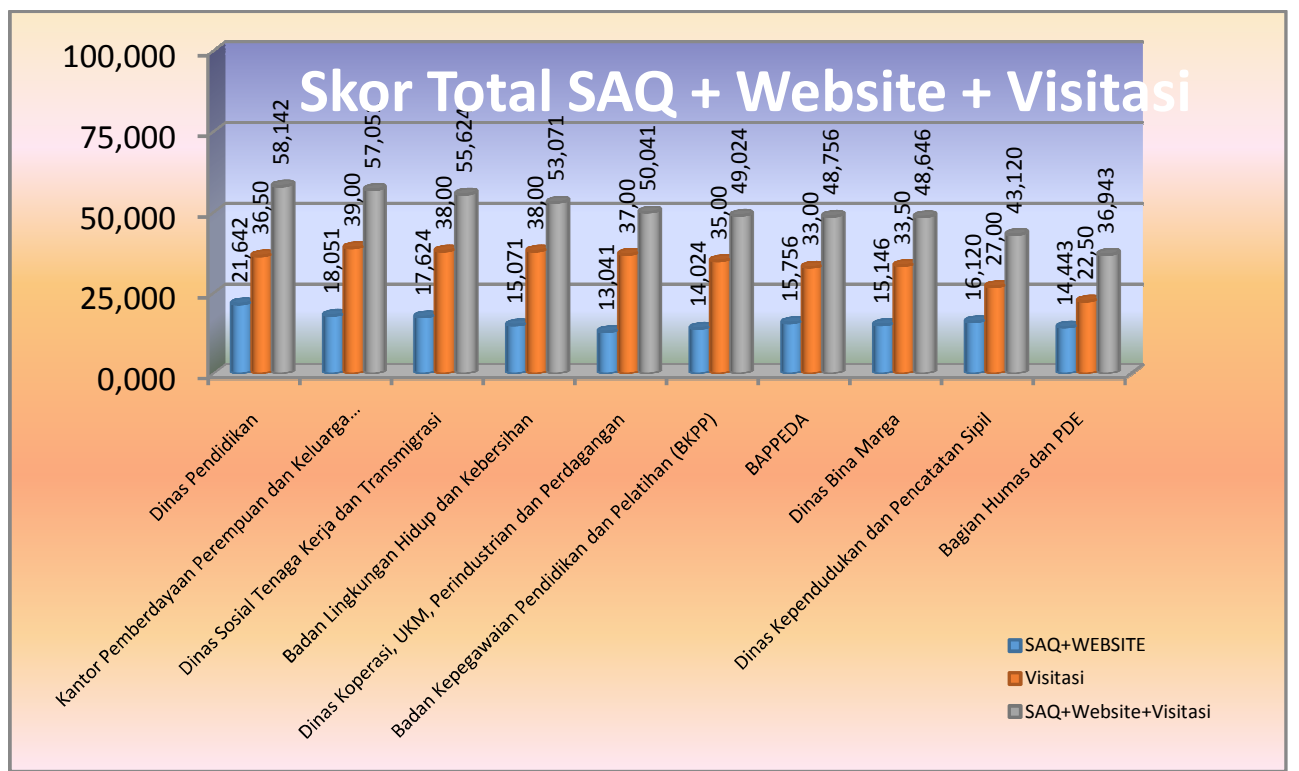

Grafik 5 : Skor Total SAQ, Website, dan Visitasi 
Berdasarkan penilaian gabungan diatas, maka dapat diketahui hasil penilaian dan peringkat PPID Pembantu SKPK Aceh Barat sebagai berikut:

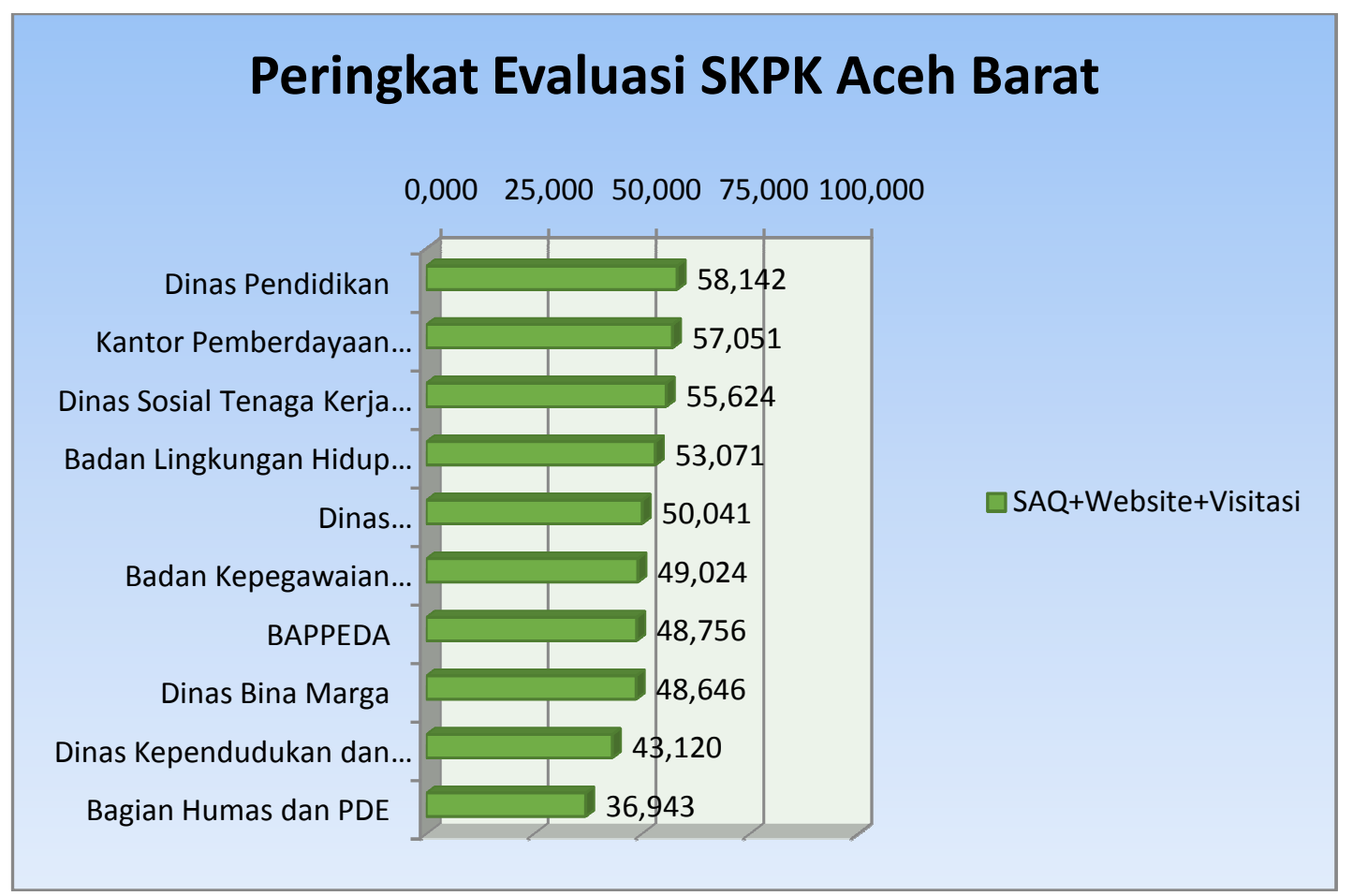

Grafik 6: Peringkat Evaluasi PPID Pembantu di Aceh Barat

\section{KESIMPULAN}

Berdasarkan hasil penilaian di atas diperoleh kesimpulan sebagai berikut:

5.1. Kepatuhan Badan Publik Pemerintahan di Kabupaten Aceh Barat melalui PPID Pembantu dalam melaksanakan UU KIP.

Kepatuhan PPID Pembantu di Aceh Barat dalam melaksanakan UU KIP masih kurang. Hal ini ditunjukkan dengan hasil penilaian gabungan antara SAQ dan kunjungan website. Secara umum nilai gabungan masih dibawah 50\%, yang bermakna masih terdapat informasi publik belum diumumkan, disediakan dan termasuk belum maksimalnya penyediaan sarana pendukung pelayanan informasi publik di Aceh Barat. Untuk itu, masih diperlukan upaya serius agar pelaksanaan UU KIP dapat dilaksanakan secara efektif berdasarkan ketentuan yang berlaku. Sehingga, tujuan pembentukan UU KIP yang antara lain mengenai peningkatan kualitas partisipasi publik dapat berlangsung dalam pembangunan di Aceh Barat.Jika dikaitkan dengan 
Katherine dan Susan (1998) yang menyatakan bahwa efektifitas partisipasi publik memerlukan dukungan sumber daya tertentu yang harus dimiliki oleh publik maupun pemerintah, maka dapat disimpulkan bahwa dengan minimnya layanan informasi publik yang disediakan PPID Pembantu di SKPK Kabupaten Aceh Barat berdampak rendahnya partisipasi publik dalam pembangunan di Aceh Barat.

5.2. Apasaja yang dapat memengaruhi kepatuhan aparatur Pemerintahan di Kabupaten Aceh Barat dalam melaksanakan UU KIP.

Sejumlah faktor yang memengaruhi kepatuhan aparatur PPID Pembantu SKPK di Aceh Barat sebagai berikut:

- Pentingnya koordinasi antar penentu kebijakan (Bupati, Sekda, dan PPID Utama) sangat membantu percepatan pelaksanaan UU KIP di Aceh Barat.

- Penyediaan sumberdaya manusia yang handal dengan jumlah yang cukup sangat membantu kepatuhan badan publik melaksanakan UU KIP.

- Dukungan pendanaan serta pendukung kerja lainnya sangat membantu upaya pelaksanaan UU KIP di Aceh Barat.

- Perubahan perilaku dan budaya aparatur pemerintahan di Aceh Barat, terutama PPID Pembantu SKPK dalam melaksanakan layanan informasi publik.

- Selain itu, partisipasi publik melalui uji akses tentang layanan informasi yang diperlukan juga menjadi factor yang berpengaruh untuk meningkatkan layanan aparatur pemerintahan di Aceh Barat.

Untuk meningkatkan pelaksanaan UU KIP di Aceh Barat, maka dapat disampaikan beberapa saran sebagai berikut:

- Pemerintahan Aceh Barat hendaknya meningkatkan jumlah dan cakupan sosialisasi tentang UU KIP pada Badan Publik serta masyarakat, baik untuk SKPK, Camat, maupun Mukim dan Gampong.

- Atasan PPID Utama Aceh Barat serta pimpinan Badan Publik lainnya untuk segera menghasilkan Daftar Informasi Publik (DIP) sesuai dengan ketentuan UU Keterbukaan Informasi Publik. Hal ini untuk memastikan agar PPID pada tiap Badan Publik dapat memberikan layanan informasi secara cepat dan mudah pada pemohon informasi. 
- PPID Utama Aceh Barat harus meningkatkan pendampingan pada PPID Pembantu SKPK, Kecamatan, serta Mukim dan Gampong agar dapat melaksanakan ketentuan UU KIP.

- PPID Utama Aceh Barat dipandang perlu melaksanakan Evaluasi Badan Publik secara rutin dengan cakupan Badan Publik yang lebih banyak, seperti institusi vertikal dan Organisasi Masyarakat Sipil (OMS).

- Pemerintahan Aceh Barat serta pimpinan lembaga lainnya agar dapat memberikan dukungan pendanaan yang memadai untuk pelaksanaan tugas dan fungsi PPID Pembantu pada SKPK, Kecamatan, serta Mukim dan Gampong.

\section{DAFTARPUSTAKA}

\section{$\underline{\text { Buku }}$}

Bagong Suyanto, Sutinah (ed). 2012. Metode Penelitian Sosial: Berbagai Alternatif Pendekatan. Jakarta: Kencana.

Bungin, Burhan, 2008. Penelitian Kualitatif Komunikasi, Ekonomi, Kebijakan Publik, dan Ilmu Sosial Lainnya. Kencana Prenada Media Group: Jakarta.

Katherine A. Graham and Susan D. Philips, 1998. "Making Public Participation More Effective: Issue for Local Government", dalam KA Graham and SD Philips (ed) Citizen Engagment: Lesson In Participation From Local Government, The Institute of Public Administration on Canada, Toronto, Ontario, Canada.

Komisi Informasi Aceh, 2013. Laporan Evaluasi Satuan Kerja Perangkat Aceh (SKPA) dan Pemerintah Kabupaten/kota Se Aceh Dalam Pelaksanaan Keterbukaan dan Layanan Informasi Publik, Komisi Informasi Aceh (KIA), Banda Aceh dan Laporan Evaluasi Implementasi Keterbukaan Informasi Publik pada Satuan Kerja Perangkat Aceh, Pemerintah Kabupaten/kota, Perguruan Tinggi Negeri dan Partai Politik di Aceh - Tahun 2015, Komisi Informasi Aceh (KIA), Banda Aceh.

Komisi Informasi Aceh, 2014 dan 2015. Laporan Evaluasi Keterbukaan Informasi Publik di Aceh, Komisi Informasi Aceh (KIA), Banda Aceh.

Komisi Informasi Aceh, 2015. Laporan Evaluasi Implementasi Keterbukaan Informasi Publik pada Satuan Kerja Perangkat Aceh, Pemerintah Kabupaten/Kota, Perguruan Tinggi Negeri dan Partai Politik Di Aceh - Tahun 2015. Komisi Informasi Aceh, Banda Aceh. 
Community: Volume 3, Nomor 1, April 2017

ISSN: 2477-5746

\section{Peraturan-peraturan}

Undang -Undang Nomor 14 Tahun 2008 Tentang Keterbukaan Informasi Publik.

Permendagri Nomor 35 Tahun 2010 Tentang Pedoman Pengelolaan dan Pelayanan

Informasi Dokumentasi di Lingkungan Depdagri dan Pemerintah Daerah.

Peraturan Komisi Informasi Nomor 1 Tahun 2010 Tentang Standar Layanan Informasi Publik.

Peraturan Gubernur Nomor 39 Tahun 2012 Tentang Pedoman Pengelolaan Informasi

dan Dokumentasi Di Lingkungan Pemerintahan Aceh.

Keputusan Bupati Aceh Barat Nomor 619 Tahun 2014 tentang Penunjukkan Pejabat Pengelola Informasi dan Dokumentasi Di Lingkungan Pemerintah Kabupaten Aceh Barat. 